\title{
Research into the use of a lean burn and a stoichiometric heavy duty engine fuelled with a blend of hydrogen and natural gas
}

\author{
L. De Simio, M. Gambino \& S. Iannaccone \\ Istituto Motori, Italian National Research Council, Napoli, Italy
}

\begin{abstract}
Energy sustainability implies the increase of share of renewable sources, as well as the reduction of inefficiencies during generation and distribution. However, a large use of renewable intermittent energy sources, such as solar and wind, in power plants and in small generators distributed could complicate the electrical grid. An important aspect of the impact of electrical networks operating on the distribution system concerns the regulation of voltage. In the case of surplus of electricity decentralized production, energy storage could be a viable solution. In this scenario the production of hydrogen by electrolysis as energy carrier, with oxygen as a byproduct, can become appealing. Hydrogen in urban areas could easily be used in blends with natural gas in urban vehicle fleets. This solution is flexible regarding the amount of hydrogen available and in any case natural gas is the best choice for the internal combustion engine for urban fleets. The use of natural gas in stoichiometric or lean burn engines guarantees a very low level of toxic emissions and zero particulate matter without the need of a trap, even after the vehicle has accumulated a considerable mileage. In particular, only the NOx emissions are harmful, since the emission of hydrocarbons are mainly composed of methane, which is not toxic to human health. In this paper the effect of the addition of hydrogen to natural gas, in the amount of $15 \%$ by volume, on the emission of a stoichiometric and a lean burn heavy duty engine was studied. The tests were carried out on the European transient cycle. The results show that with the stoichiometric engine no special attention must be put in the supply change while with the lean burn engine the problem of poor NOx control suggests adjusting the calibration of ignition; with the aim of not compromising the engine emission.
\end{abstract}

Keywords: hydrogen, hydromethane, natural gas, ETC, sustainability. 


\section{Introduction}

The evolution of the electricity grid is a key challenge in Europe to enable the development of renewables sources. In fact, solar and wind energy are abundant and distributed, but are also intermittent and characterized by a poor ability to control and predict the amount of electricity that can be produced. Distributed generation also implies that the grid should become bidirectional. Therefore, the distribution network will switch from a passive to an active role [1-3], changing the way in which electricity is produced, transmitted and consumed. An important aspect of the impact of electrical networks operating on the distribution system concerns the regulation of voltage. The fluctuating nature of renewable energy will require storage systems or demand management while the distribution of generation points will involve node voltage control. In this scenario also a flexible coproduction of hydrogen $\left(\mathrm{H}_{2}\right)$ as energy carrier could be a viable solution [4-8]. The electricity network should manage in an intelligent way different energy vectors, distributed power generators and dispersed energy storage devices, instead of the electricity alone [9].

Hydrogen in urban areas could be easily used in blends with natural gas in an urban bus natural gas fleet. This solution is flexible regarding the amount of hydrogen available. Compressed Natural Gas (CNG) has proved to be a concrete alternative to gasoline and diesel fuels for vehicle propulsion. Natural gas is a clean fuel since toxic compounds like sulphur, or potential toxic, like benzene and higher molecular weight hydrocarbons, or highly reactive such as olefins, are absent. Nowadays, most CNG engines operate in spark ignition (SI) mode, for both light and heavy-duty application. Particularly in this latter case the typical disadvantages of a CNG fuel tank weight and allocation are overcome because of the wide space availability and the small relative increase in weight. Moreover in the case of public transportation in urban areas, the route is scheduled and therefore the NG option can be chosen according to the autonomy range. The utilization of pure hydrogen, in substitution of $\mathrm{CNG}$, in a spark ignition engine, drastically reduces vehicle operating range (by about $70 \%$ compared to methane, $\mathrm{CH}_{4}$ ) due to its lower energy density by volume. Furthermore, $\mathrm{H}_{2}$ has a low ignition energy in air $\left(0.02 \mathrm{~mJ}\right.$ versus 0.29 of $\mathrm{CH}_{4}$, at stoichiometric conditions [10]), which ensures the combustion even with very lean mixtures but makes it subject to pre-ignition phenomena by contact with hot spots or residual gas. The pre-ignition, unlike the knocking, cannot only be controlled with the ignition timing, but requires substantial modifications to the engine. The use of methanehydrogen mixtures containing $\mathrm{H}_{2}$ between 10 and $30 \%$ by volume offers instead the opportunity to exploit the positive aspects related to hydrogen without substantial modification of already existing natural gas engines, avoiding the drawbacks of the use of pure hydrogen.

Bibliographic data highlight a flame front speed propagation increasing when $\mathrm{H}_{2}$ is added to $\mathrm{NG}[11,12]$. At the same time, a reduction of carbon monoxide (CO) and unburned hydrocarbons (THC) occurs, with benefits on thermodynamic efficiency. On the contrary, nitrogen oxide (NOx) emissions could be higher for more elevated temperatures at stoichiometric 
conditions [13]. Hydrogen added to natural gas gives us the possibility to expand the lean burn limit [14-16], due to a more stable combustion [17]. A more stable combustion permits us to use higher exhaust gas recirculation to optimize the engine [18-20]. A review of $\mathrm{H}_{2}$ use in internal combustion engine is given in [21]. As hydrogen is a carbon-free fuel, the reduction in carbon dioxide $\left(\mathrm{CO}_{2}\right)$ emissions is a direct function of $\mathrm{H}_{2}$ content in the blend, at the same engine efficiency. For blends containing a $30 \%$ in volume of $\mathrm{H}_{2}$, more than $10 \% \mathrm{CO}_{2}$ reduction is expected. In any case the way of hydrogen production represents a crucial aspect.

In this paper two heavy duty engines for urban bus application, a stoichiometric and a lean burn, were tested on the European transient test (ETC) cycle. The engines were fuelled with NG and with a blend of NG and $15 \%$ by volume of $\mathrm{H}_{2}$. The effect on engine exhaust emission was examined.

\section{Experimental setup}

The experimental activity was carried out on two commercial SI heavy duty engines. A $200 \mathrm{~kW}$ stoichiometric engine (Table 1 and Figure 1) equipped with a three way catalyst (TWC) and an oxygen lambda sensor and a $170 \mathrm{~kW}$ lean burn engine (Table 2 and Figure 2) equipped with an oxidation catalyst.

Table 1: $\quad$ Stoichiometric SI heavy duty engine main characteristics.

\begin{tabular}{|r|l|}
\hline \multicolumn{2}{|c|}{ Turbocharged intercooler 6-cylinder in line } \\
\hline Total displacement & $7800 \mathrm{~cm} 3$ \\
\hline Bore x stroke & $115 \times 125 \mathrm{~mm}$ \\
\hline Compression ratio & $11: 1$ \\
\hline Rated power & $200 \mathrm{~kW} @ 2100 \mathrm{rpm}$ \\
\hline Rated torque & $1100 \mathrm{Nm} \mathrm{@} 1100 \div 1650 \mathrm{rpm}$ \\
\hline Boost pressure & $180 \mathrm{kPa}$, with waste gate valve \\
\hline Intercooler & Air to water (external line) \\
\hline NG feeding system & Electronic timed multi-point injection \\
\hline Power Density & $25.6 \mathrm{~kW} / \mathrm{dm} 3$ \\
\hline
\end{tabular}

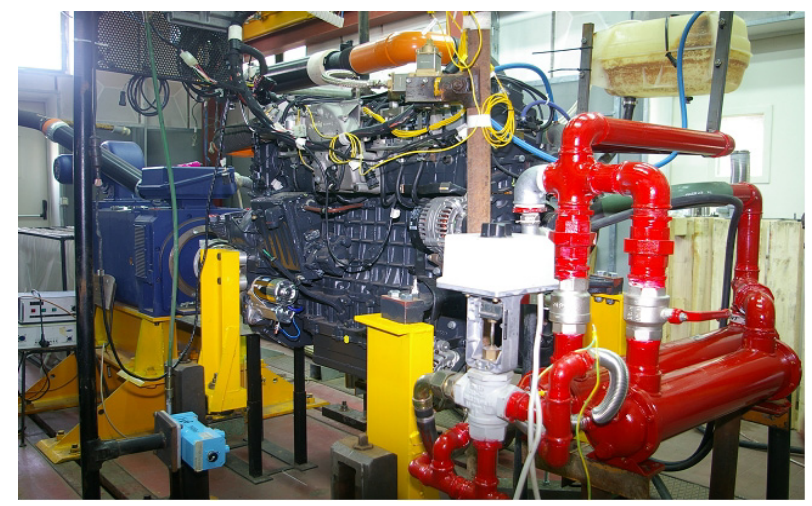

Figure 1: $\quad$ Stoichiometric heavy duty NG engine at dynamic test bed. 
Table 2: $\quad$ Lean burn SI heavy duty engine main characteristics.

\begin{tabular}{|r|l|}
\hline \multicolumn{2}{|c|}{ Turbocharged intercooler 6-cylinder in line } \\
\hline Total displacement & $6883 \mathrm{~cm} 3$ \\
\hline Bore x stroke & $106 \times 130 \mathrm{~mm}$ \\
\hline Compression ratio & $10.5: 1$ \\
\hline Rated power & $170 \mathrm{~kW} @ 2200 \mathrm{rpm}$ \\
\hline Rated torque & $810 \mathrm{Nm} @ 1200 \div 1800 \mathrm{rpm}$ \\
\hline Boost pressure & $124 \mathrm{kPa} @ 2200 \mathrm{rpm}$ \\
\hline Intercooler & Air to Air \\
\hline NG feeding system & Electronic timed multi-point injection \\
\hline Power Density & $24.7 \mathrm{~kW} / \mathrm{dm} 3$ \\
\hline
\end{tabular}

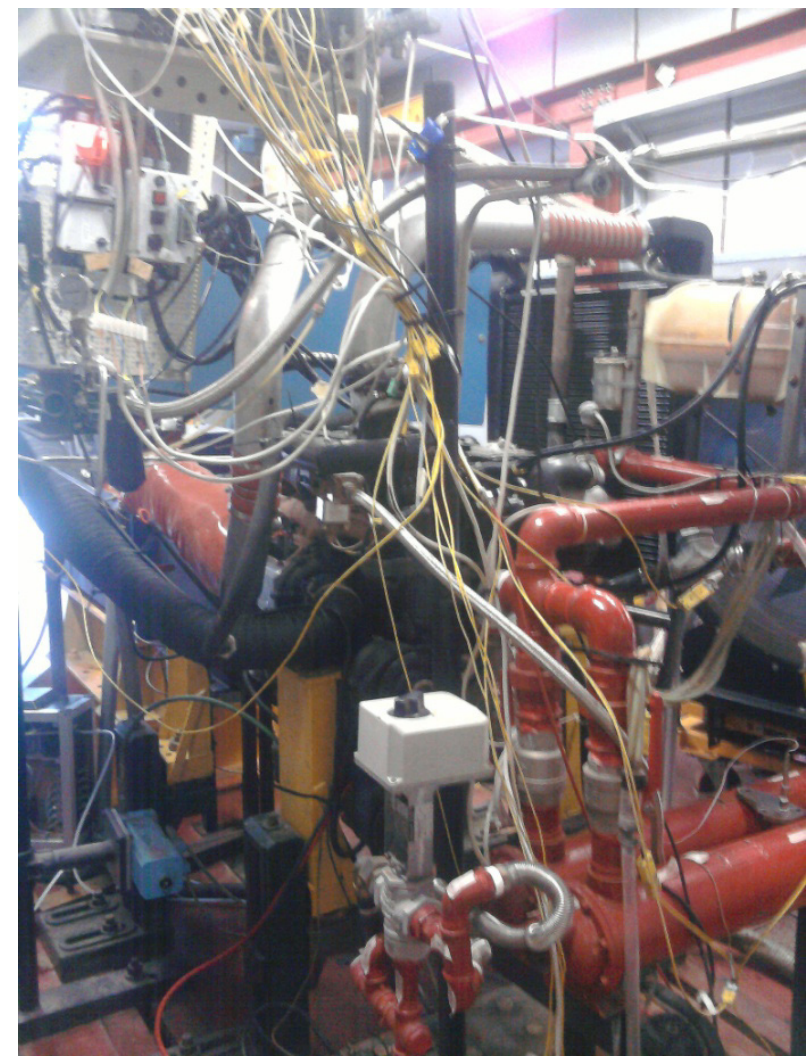

Figure 2: $\quad$ Lean burn heavy duty NG engine at dynamic test bed.

The engines were fuelled with NG and with a blend of pure methane and $15 \%$ of $\mathrm{H}_{2}$ by volume also named "hydromethane" (HCNG). The characteristics of the fuels used in the tests are reported in Table 3. The NG used has $85 \%$ of methane content while the rest is principally constituted of ethane and inert gases. The $\mathrm{HCNG}$, represents instead an enriched NG in which substances different from methane were replaced by hydrogen. 
Table 3: $\quad$ Characteristics of tested fuels.

\begin{tabular}{|c|c|c|c|c|c|c|c|}
\cline { 2 - 8 } \multicolumn{1}{c|}{} & $\begin{array}{c}\mathrm{CH} 4 \\
\% \text { vol. }\end{array}$ & $\begin{array}{c}\mathrm{H}_{2} \\
\% \text { mass }\end{array}$ & $\begin{array}{c}\text { SAFR } \\
\mathrm{kg} / \mathrm{kg}\end{array}$ & $\begin{array}{c}\mathrm{LHV} \\
\mathrm{MJ} / \mathrm{kg}\end{array}$ & $\begin{array}{c}\rho^{*} \\
\mathrm{~kg} / \mathrm{Sm}^{3}\end{array}$ & $\begin{array}{c}\mathrm{H} / \mathrm{C} \\
\mathrm{n} / \mathrm{m}\end{array}$ & $\begin{array}{c}\mathrm{CO}_{2} \\
\mathrm{~g} / \mathrm{MJ}\end{array}$ \\
\hline $\mathrm{NG}$ & 85 & 0 & 15.7 & 45.8 & 0.83 & 3.7 & 57 \\
\hline $\mathrm{HCNG}$ & 85 & 2.13 & 17.3 & 50.7 & 0.63 & 4.3 & 53 \\
\hline
\end{tabular}

${ }^{*}$ Density at 1 bar and $15^{\circ} \mathrm{C}$

The experimental activity was carried out on an AVL Puma 5 dynamic test bed, integrated with an emission test bank, able to control the engine and carry out continuous measurements during the ETC respecting all the constraints imposed by the legislation. The ETC [22], which is the test approval for gaseous SI heavy duty engines, is fixed through a table of normalized values of speed and torque. The full torque curve of the engine is used to denormalize that table. The dynamic test has a duration of $1800 \mathrm{~s}$ and can be split in three subsets of $600 \mathrm{~s}$ : in the first has very sudden changes of speed and load typical of the operation in urban areas, with continuous phases of "stop and go". The second subset is related to rural roads with less intensive variations of speed and load, while the last is representative of motorway running. Figure 3 shows the profiles of normalized torque and speed to run during the ETC. More details about the instrumentation used to run the ETC tests are reported in Table 4.

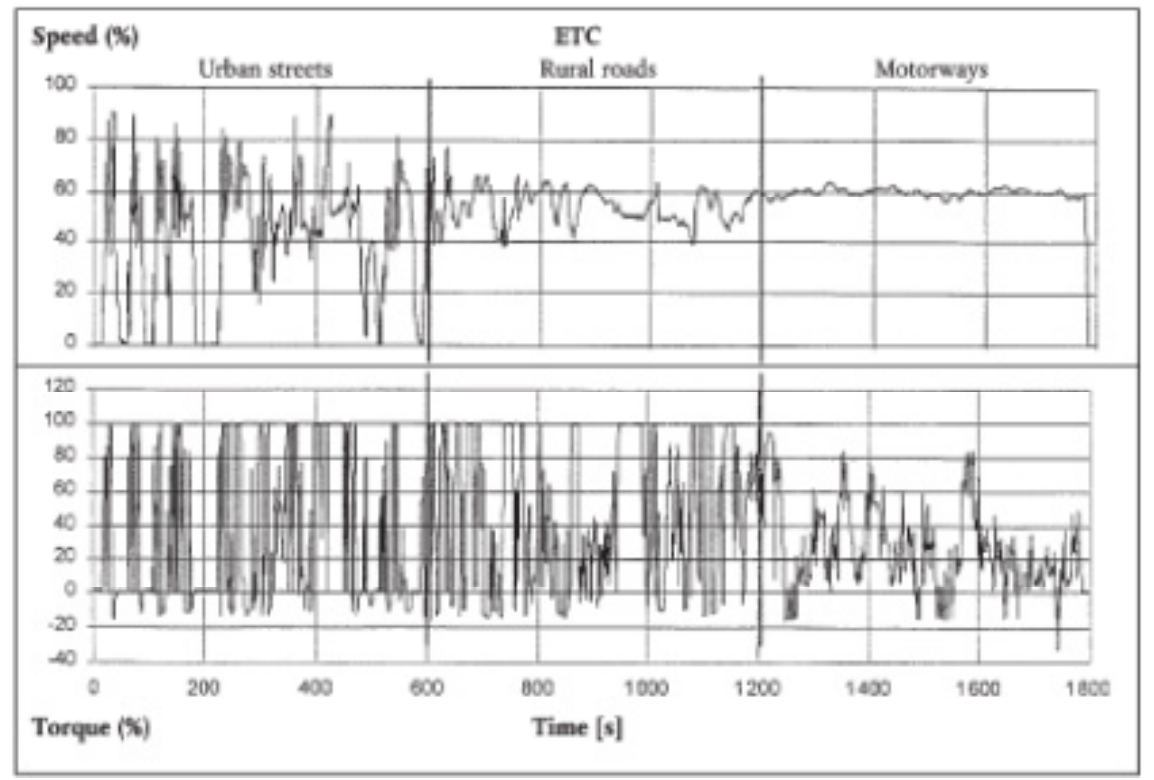

Figure 3: A graphical display of the ETC dynamometer schedule [22]. 
Table 4: Instrumentation for emission measurement according the ETC test.

\begin{tabular}{|c|c|c|c|}
\hline Unit & Type & Range & Accuracy \\
\hline TORQUE & TORQUE FLANGE HBN T 10F & $2000 \mathrm{Nm}$ & $\begin{array}{l} \pm 0.2 \% \text { of } \\
\text { reading }\end{array}$ \\
\hline SPEED & AFA AVL DINAMOMETER & $3500 \mathrm{rpm}$ & $\begin{array}{c}<0.2 \% \text { of } \\
\text { reading }\end{array}$ \\
\hline $\begin{array}{l}\text { FUEL MASS } \\
\text { FLOW METER }\end{array}$ & MICRO MOTION ELITE & $50 \mathrm{~kg} / \mathrm{h}$ & $<1 \%$ of reading \\
\hline $\begin{array}{c}\text { AIR MASS } \\
\text { FLOW METER }\end{array}$ & ABB SENSY FLOW P & $1200 \mathrm{~kg} / \mathrm{h}$ & $\pm 1 \%$ of reading \\
\hline $\begin{array}{c}\text { ATMOSPHERIC } \\
\text { INTAKE } \\
\text { EXHAUST } \\
\text { PRESSURE }\end{array}$ & DRUCK PT X 1400 & $\begin{array}{c}800-1200 \text { mbar } \\
400 \text { mbar }\end{array}$ & $\begin{array}{c} \pm 0.1 \mathrm{kPa} \\
( \pm 0.25 \%) \\
\text { of range }\end{array}$ \\
\hline $\begin{array}{c}\text { OTHER } \\
\text { PRESSURES }\end{array}$ & DRUCK PT X 1400 & - & $\begin{array}{l} \pm 0.25 \% \\
\text { of range }\end{array}$ \\
\hline TEMPERATURE & - & - & $\pm 1 \%$ of reading \\
\hline THC & \multirow{2}{*}{ MULTIFID 14 EGA } & $\begin{array}{c}0-10000 \\
\text { ppm C }\end{array}$ & \multirow{2}{*}{$0.5 \%$ of range } \\
\hline $\mathrm{CH} 4$ & & $\begin{array}{l}1-10000 \\
\text { ppm } C_{1}\end{array}$ & \\
\hline $\mathrm{CO}$ & URAS 14 EGA & $0-10 \%$ & $<1 \%$ of range \\
\hline $\mathrm{NO}_{\mathrm{X}}$ & CLD ECOPHYSICS & $0-5000$ & $<1 \%$ of range \\
\hline NO & CLD 700 REHT PERFORMANCE & & \\
\hline $\mathrm{CO}_{2}$ & URAS 14 EGA & $0-20 \%$ & $1 \%$ of range \\
\hline $\mathrm{O}_{2}$ & MACROS 16 EGA & $0-25 \%$ & $0.5 \%$ of range \\
\hline $\begin{array}{l}\text { PARTICULATE } \\
\text { SAMPLING } \\
\text { SYSTEM }\end{array}$ & CONTROL SYSTEM PSS20 & $1.5 \mathrm{~m}^{3} / \mathrm{h}$ & $\pm 0.2 \%$ of range \\
\hline $\begin{array}{c}\text { PT } \\
\text { ELECTRONIC } \\
\text { BALANCE }\end{array}$ & SARTORIUS 4503 MICRO & $4.1 \mathrm{~g}$ & $\begin{array}{c} \pm 5 \mathrm{ng} \\
\text { of reading }\end{array}$ \\
\hline
\end{tabular}

The two diagrams of Figure 4 represent two short sections relating to the torque profile of the urban section in the range $220 \div 260$ s of the ETC cycle $(a)$ and of the motorway in the range of $1300 \div 1450 \mathrm{~s}(b)$. The figure highlights the fact that the engine must operate with considerable variations in performance, which require very fast and accurate control for a correct execution of the cycle. 


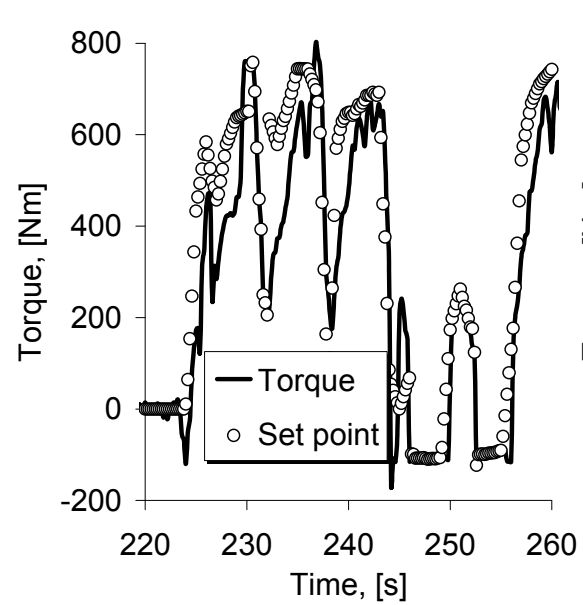

(a)

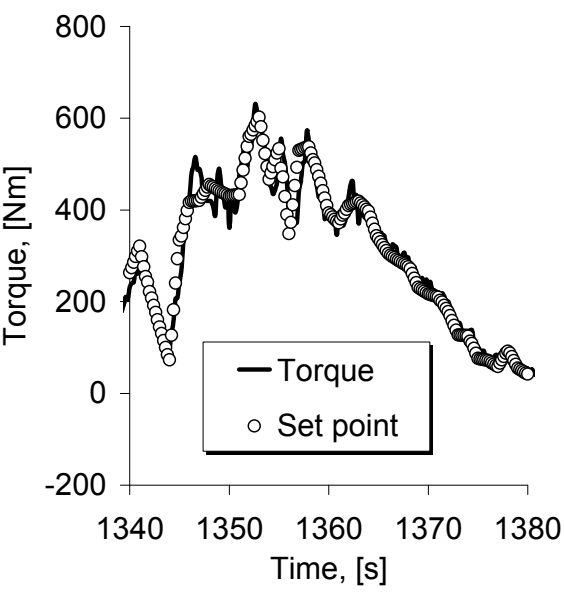

(b)

Figure 4: Torque measured for the lean burn engine compared with the set point of the ETC cycle: (a) part of urban phase, (b) part of motorway phase.

\section{Results}

For the stoichiometric engine the comparison between the two test fuels has been carried out without changing the electronic control unit (ECU) calibration. Therefore the same spark advance (SA) map was used for both CNG and HCNG fuelling. For the lean burn engine, instead, the SA map was adjusted. The experimental activity has resulted in establishing a SA reduction of 2.5 crank angle degrees on the whole engine map. In Table 5 the comparison between the results obtained on the ETC test with the two engines and the two tested fuels is reported. Apart from the $\mathrm{CH}_{4}$ emissions, $\mathrm{CO}$, $\mathrm{NMHC}$, and $\mathrm{NOx}$ emissions were within the enhanced environmentally friendly vehicle (EEV) limits in all the cases. The control of $\mathrm{CH}_{4}$ emission is critical and strongly dependent on the exhaust temperature. Particulate matter (PT) emissions were considerably under the limits, especially for the lean burn engine. Slightly lower energy consumption was obtained with the lean burn engine. Using HCNG a reduction of $\mathrm{CO}_{2}$ emission due to a higher $\mathrm{H} / \mathrm{C}$ was obtained.

For the stoichiometric engine the $\mathrm{CO}$ emissions are the most critical and this is due to the fact that the ECU sets a slightly rich mixture to permit a high efficiency of NOx reducing to the catalyst. Therefore, changing from $\mathrm{CNG}$ to $\mathrm{HCNG}$ gives some benefits; in fact the reduction of $\mathrm{H} / \mathrm{C}$ of the fuel also results in a reduction of $\mathrm{CO}$ emissions. Instead, although the $\mathrm{NOx}$ emissions increase upstream the catalyst, the high NOx conversion efficiency does not increase NOx emission downstream the catalyst when HCNG is used (Figure 5). NOx emission increasing upstream the catalyst with $\mathrm{HCNG}$ is due to a faster combustion at parity of SA. In particular the burning gravity centre (BGC), the 
Table 5: Comparison of results of the ETC tests for both the stoichiometric and the lean burn engine with the EEV limits.

\begin{tabular}{|c|c|c|c|c|c|c|c|}
\hline & $\mathrm{CO}$ & NMHC & CH4 & NOx & PT & $\mathrm{CO} 2$ & BSEC \\
\hline & & & $\mathrm{g} / \mathrm{kWh}$ & & & $\mathrm{g} / \mathrm{kWh}$ & $\mathrm{MJ} / \mathrm{kWh}$ \\
\hline $\begin{array}{l}\text { Stoichiometric } \\
200 \mathrm{~kW} \text { CNG }\end{array}$ & 2.36 & 0.07 & 0.68 & 0.49 & $<0.01$ & 714 & 12.5 \\
\hline $\begin{array}{l}\text { Stoichiometric } \\
200 \mathrm{~kW} \text { HCNG }\end{array}$ & 2.15 & 0.00 & 0.67 & 0.52 & $<0.01$ & 670 & 12.7 \\
\hline $\begin{array}{c}\text { Lean burn } \\
170 \mathrm{~kW} \text { CNG }\end{array}$ & 0.00 & 0.06 & 2.32 & 1.37 & $<0.001$ & 705 & 12.4 \\
\hline $\begin{array}{c}\text { Lean burn } \\
170 \mathrm{~kW} \text { HCNG }\end{array}$ & 0.00 & 0.00 & 2.26 & 1.64 & $<0.001$ & 643 & 12.2 \\
\hline \multicolumn{8}{|l|}{ Limits } \\
\hline EURO III 2000 & 5.45 & 0.78 & 1.60 & 5.00 & 0.16 & & \\
\hline EURO IV 2005 & 4.00 & 0.55 & 1.10 & 3.50 & 0.03 & & \\
\hline EURO V 2008 & 4.00 & 0.55 & 1.10 & 2.00 & 0.03 & & \\
\hline EEV & 3.00 & 0.40 & 0.65 & 2.00 & 0.02 & & \\
\hline
\end{tabular}

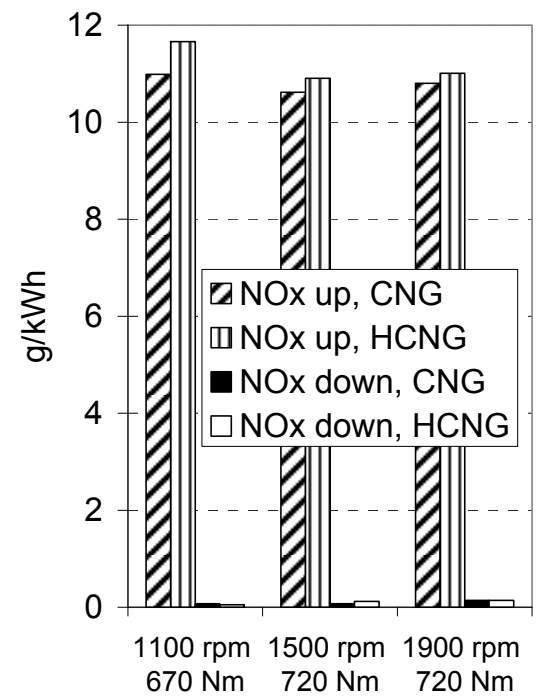

Figure 5: NOx emission upstream and downstream the TWC for the stoichiometric engine with $\mathrm{CNG}$ and $\mathrm{HCNG}$ at steady state.

crank angle at which $50 \%$ of the fuel mass is burned is advanced in the case of HCNG, Figure 6(b). The pressure cycles, Figure 6(a), have been measured in the combustion chamber of the stoichiometric engine with KISTLER piezoelectric pressure transducers (sensitivity $26 \mathrm{pC} / \mathrm{bar}$ ). Pressure cycles were measured as mean values of 128 consecutive cycles. 


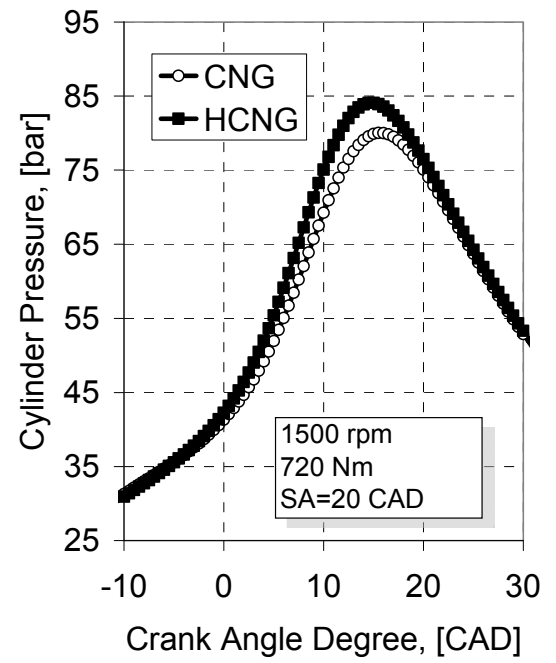

(a)

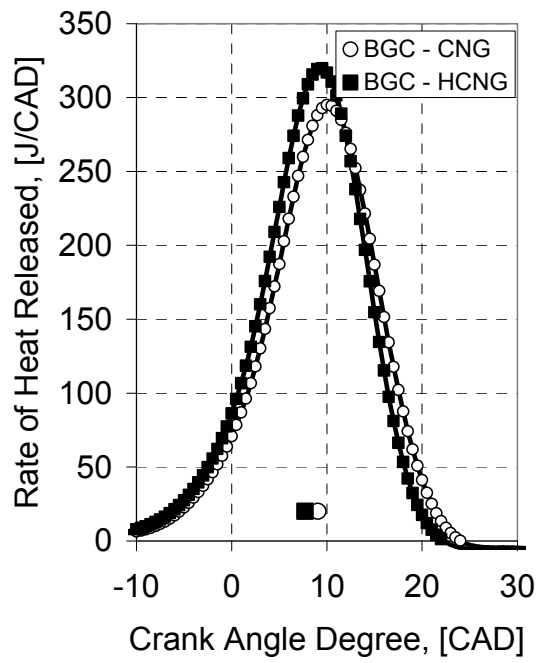

(b)

Figure 6: $\quad \mathrm{CNG}$ and $\mathrm{HCNG}$ cylinder pressure cycles $(a)$ and heat release rate curves $(b)$ at $1500 \mathrm{rpm}$ and $720 \mathrm{Nm}$ with the same SA calibration.

For the lean burn engine NOx control is possible only in the combustion chamber; a post-reduction system not being present. In addition for this engine the lowest exhaust temperature makes the conversion efficiency of the oxidation catalyst respect to the stoichiometric engine more variable. In Table 6 it is possible to analyze both the two mentioned problems for the lean burn engine. Looking at the first and the second lines, $\mathrm{CO}$ and $\mathrm{NMHC}$ conversion is almost complete while $\mathrm{CH}_{4}$ is reduced by about $50 \%$. Considering the standard deviation of results, there is a low variation of engine $\mathrm{CH}_{4}$ exhaust emission upstream of the catalyst and a high variation downstream of the catalyst. This is due to the efficiency of the conversion system, in particular in the first phase of the ETC cycle. In fact, for this kind of engine also the presence of insulation on the exhaust could influence the $\mathrm{CH}_{4}$ conversion efficiency of the catalyst. Thus the results on $\mathrm{CH}_{4}$ obtained could be reduced with a different exhaust system. About NOx emission, from the second and third lines, an increase of more than $80 \%$ with HCNG is obtained when the ECU SA calibration is not adjusted. Therefore, in the fourth line, an optimization of the SA calibration was performed to retain the same level of NOx emission of the CNG case.

\section{Conclusion}

The use of natural gas in stoichiometric or lean burn engine guarantees very low level of toxic emission and zero particulate matter. Hydrocarbon emissions are mainly constituted by methane that is not toxic for human health therefore only NOx emissions are harmful. In this paper the effect of hydrogen addition to 
Table 6: Results of the ETC tests for the lean burn engine with different conditions.

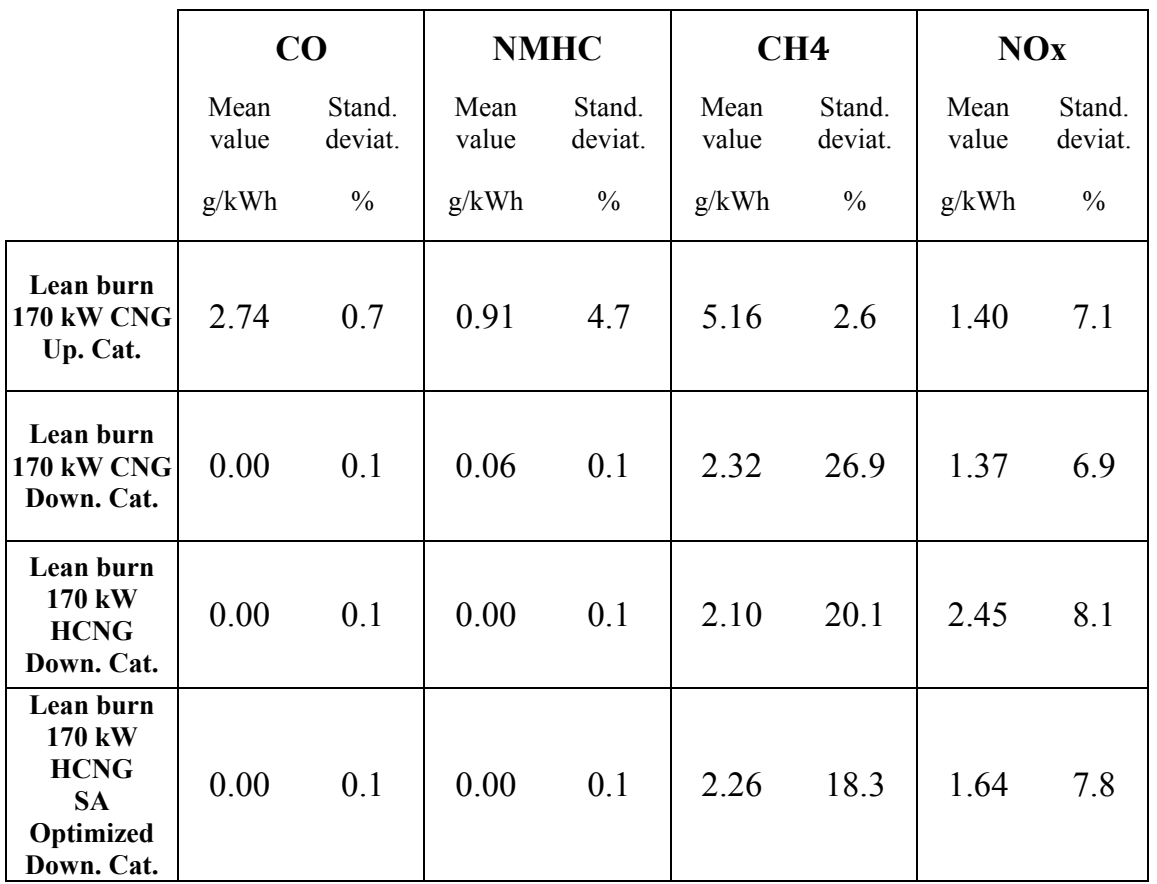

natural gas in the amount of $15 \%$ by volume on emission of a stoichiometric and a lean burn engine was studied. The study was carried out on the basis of European transient cycle tests. The results highlight that with a stoichiometric engine no particular attention should be placed when the engine is switched from $\mathrm{CNG}$ to $\mathrm{HCNG}$, in fact the NOx increasing is only upstream the three way catalyst. With a lean burn engine ECU SA adjustment should be required when the engine is fuelled with HCNG with the aim of not compromising the very low engine out emissions with NOx increasing.

\section{Nomenclature}

\begin{tabular}{|l|l|}
\hline CNG & Compressed natural gas \\
\hline BGC & Burning gravity centre \\
\hline BSEC & Brake specific energy consumption \\
\hline CAD & Crank angle degree \\
\hline CH4 & Methane \\
\hline CO & Carbon monoxide \\
\hline CO2 & Carbon dioxide \\
\hline ECU & Electronic control unit \\
\hline EEV & Enhanced environmentally vehicles \\
\hline ETC & European transient cycle \\
\hline H2 & Hydrogen \\
\hline
\end{tabular}

\begin{tabular}{|l|l|}
\hline HCNG & Hydromethane \\
\hline LHV & Lower heating value \\
\hline NMHC & Non methane hydrocarbon \\
\hline NOx & Nitrogen oxides \\
\hline PT & Particulate \\
\hline SA & Spark advance \\
\hline SAFR & Stoichiometric air fuel ratio \\
\hline SI & Spark ignition \\
\hline THC & Total unburned hydrocarbons \\
\hline TWC & Three way catalyst \\
\hline
\end{tabular}




\section{References}

[1] Battaglini, A., Lilliestam, J., Haas, A., and Patt, A. (2009). Development of SuperSmart Grids for a more efficient utilisation of electricity from renewable sources. Journal of Cleaner Production, 17(10), 911-918.

[2] Hammons, T. (2008). Integrating renewable energy sources into European grids. International Journal of Electrical Power and Energy Systems, 30(8), 462-47.

[3] Crossley, P., and Beviz, A. (2010). Smart energy systems: Transitioning renewables onto the grid. Renewable Energy Focus, 11(5), 54-59.

[4] Hemmes, K., Guerrero, J. M., and Zhelev, T. (2011). Highly efficient distributed generation and high-capacity energy storage. Chemical Engineering and Processing: Process Intensification, 51, 18-31.

[5] Fingersh, L.J. (2003). Optimized Hydrogen and Electricity Generation from Wind, NREL/TP-500-34364.

[6] Delucchi, M. a., and Jacobson, M. Z. (2011). Providing all global energy with wind, water, and solar power, Part II: Reliability, system and transmission costs, and policies. Energy Policy, 39(3), 1170-1190.

[7] Kelly, N. A., Gibson, T. L., Cai, M., Spearot, J. A., and Ouwerkerk, D. B. (2010). Development of a renewable hydrogen economy: Optimization of existing technologies. International Journal of Hydrogen Energy, 35(3), 892-899.

[8] Barton, J., and Gammon, R. (2010). The production of hydrogen fuel from renewable sources and its role in grid operations. Journal of Power Sources, 195(24), 8222-8235.

[9] Orecchini, F., and Santiangeli, A. (2011). Beyond smart grids - The need of intelligent energy networks for a higher global efficiency through energy vectors integration. International Journal of Hydrogen Energy, 36(13), 8126-8133.

[10] Chapman, K.S., Patil, A. (2008). "Performance, Efficiency, and Emissions Characterization of Reciprocating Internal Combustion Engines Fuelled with Hydrogen/Natural Gas Blends", Final Technical Report, DOE Award DE-FC26-04NT42234.

[11] Boulouchos K., Dimopoulos P., Hotz R., Rechsteiner C., Soltic P. (2007). "Combustion Characteristics of Hydrogen-Natural Gas Mixtures in Passenger Car Engines, SAE paper -24-0065.

[12] Andersson T. (2002). "Hydrogen Addition for Improved Lean Burn Capability on Natural Gas Engine", Rapport SGC 134 ISSN 1102-7371, Lund Institute of Technology.

[13] Bysveen, M. (2007). Engine characteristics of emissions and performance using mixtures of natural gas and hydrogen. Energy, 32(4), 482-489.

[14] Park, C., Kim, C., Choi, Y., Won, S., and Moriyoshi, Y. (2011). The influences of hydrogen on the performance and emission characteristics of a heavy duty natural gas engine. International Journal of Hydrogen Energy, 36(5), 3739-3745. 
[15] Xu, J., Zhang, X., Liu, J., and Fan, L. (2010). Experimental study of a single-cylinder engine fueled with natural gas-hydrogen mixtures. International Journal of Hydrogen Energy, 35(7), 2909-2914.

[16] Ma, F., Wang, M., Jiang, L., Deng, J., Chen, R., Naeve, N., and Zhao, S. (2010). Performance and emission characteristics of a turbocharged sparkignition hydrogen-enriched compressed natural gas engine under wide open throttle operating conditions. International Journal of Hydrogen Energy, 35(22), 12502-12509.

[17] Wang, J., Chen, H., Liu, B., and Huang, Z. (2008). Study of cycle-by-cycle variations of a spark ignition engine fueled with natural gas-hydrogen blends. International Journal of Hydrogen Energy, 33(18), 4876-4883.

[18] Hu, E., Huang, Z., Liu, B., Zheng, J., and Gu, X. (2009). Experimental study on combustion characteristics of a spark-ignition engine fueled with natural gas-hydrogen blends combining with EGR. International Journal of Hydrogen Energy, 34(2), 1035-1044.

[19] Dimopoulos, P., Rechsteiner, C., Soltic, P., Laemmle, C., and Boulouchos, $K$. (2007). Increase of passenger car engine efficiency with low engine-out emissions using hydrogen-natural gas mixtures: A thermodynamic analysis. International Journal of Hydrogen Energy, 32(14), 3073-3083.

[20] Dimopoulos, P., Bach, C., Soltic, P., and Boulouchos, K. (2008). Hydrogen-natural gas blends fuelling passenger car engines: Combustion, emissions and well-to-wheels assessment. International Journal of Hydrogen Energy, 33(23), 7224-7236.

[21] Escalante Soberanis, M. A., and Fernandez, A. M. (2010). A review on the technical adaptations for internal combustion engines to operate with gas/hydrogen mixtures. International Journal of Hydrogen Energy, 35(21), 12134-12140.

[22] EC 2005. Directive 2005/55/EC of the European Parliament and of the Council of 28 September 2005. 